\title{
Assessment of Phytoavailability in the Cherry Tomato Plants Exposed to Lead and Chromium in a Nutrient Solution
}

\author{
Loubna Azariz ${ }^{1,2}$, Souad Elblidi' ${ }^{2}$, Ahmed Yahyaoui' ${ }^{1}$, Mohamed Fekhaoui ${ }^{2}$ \\ ${ }^{1}$ Laboratory of Zoology and General Biology, Department of Biology, Faculty of Sciences, Mohammed V University in Rabat, \\ Rabat, Morocco \\ ${ }^{2}$ Pollution Unit, Department of Zoology and Animal Ecology, Scientific Institute, Mohammed V University in Rabat, \\ Rabat, Morocco \\ Email: Loubna.aza@gmail.com
}

How to cite this paper: Azariz, L., Elblidi, S., Yahyaoui, A. and Fekhaoui, M. (2017) Assessment of Phytoavailability in the Cherry Tomato Plants Exposed to Lead and Chromium in a Nutrient Solution. Journal of Geoscience and Environment Protection, 5, 176-188.

https://doi.org/10.4236/gep.2017.59013

Received: July 10, 2017

Accepted: September 12, 2017

Published: September 15, 2017

Copyright (c) 2017 by authors and Scientific Research Publishing Inc. This work is licensed under the Creative Commons Attribution International License (CC BY 4.0).

http://creativecommons.org/licenses/by/4.0/

\begin{abstract}
The phytoavailability of lead and chromium in cherry tomatoes Lycopersicon esculentum was studied both at the level of different parts of the plant (roots, stem, leaves and fruits) and at the level of its concentration in water and cultivation soil of. Two experiments are thence carried out by planting in bioponics, in a patented BIOTOP device, plants which are exposed via their root system to concentrations of $5 \mathrm{ppm}, 10 \mathrm{ppm}$ and $20 \mathrm{ppm}$ of each contaminant (lead or chromium) in a nutrient solution. The results show that lead accumulates mainly in the roots with a significant amount as to allow its translocation into the stem and leaves, while only a small amount reaches the fruit. The results also show that when the concentration increases the lead content in the roots also increases, but decreases in the fruits with three floral bouquets. Conversely, the chromium substance decreases in the roots and increases in the fruit. Based on these results, we note that the average distribution of lead in the edible part of the plant is much higher than that of chromium, and also lead presence in the plant is higher compared to that of chromium.
\end{abstract}

\section{Keywords}

Cherry Tomatoes, Lead, Chromium, Phytoavailability, Bioponics

\section{Introduction}

The world population has been exposed to low concentrations of metals mainly via water and food; some, however, are exposed to toxic concentrations via professional activities such as mining. With time, the range of potentially toxic 
metal sources has expanded substantially by effect of the increasing industrial or agricultural activities [1]. Their presence in the environment makes us wonder about the risk of them being transferred into the food chain via cultivated crops, threatening thereby the sanitary quality of our food and, thus, our health [2] [3] [4].

Some heavy metals however, at low doses are essential micronutrients for plants (e.g. Ni, Cr, $\mathrm{Zn}, \mathrm{Cu}$ ) but at high doses, may cause a growth inhibition or a metabolic disorders for most plant species [5]. The presence of element trace in agricultural environments can come from atmospheric fall-out, pesticide, chemical fertilizers and irrigation with water of poor quality [6]. Excessive concentration of trace elements in soil compartment or substratum will be directly transferred to the plant during its development. As a result of a series of successive processes, the element in the solid phase of soil will be transferred into the soil solution and eventually to the plant tissues themselves. That's what we called phytoavailability.

The laboratory experiments conducted in the field of phytoavailability of trace elements in plants of cherry tomato were carried out either for soil cultivation or for hydroponics, the need to investigate a new method to understand more and more the behavior of this edible plant in dealing with metallic stress of two trace elements that are lead and chromium. This new technique that called "bioponics" combines the advantages of hydroponics with an effective biological nutrition program that help maintain the essential microbiology of the plant in the liquid medium of the plant, this cropping system saves water and fertilizers and develops a dense root carpet. The effect of contamination was evaluated by examining their content in different parts of the plant, in water and cultivation soil.

The estimation of the phytoavailability of a trace element in soil remains an approach widely used for the prediction of the deficiency or toxicity of an element in a plant. In fact they are two conventional approaches: 1) to measure its extractability, that is, its ability to pass into solution under the effect of more or less mild chemical extractants, or 2) analyze its content inside the plant [7]. As for our approach we shall go for the second.

This experiment allows us to make a simplified illustration of the complex reality pertaining to the translocation of lead and chromium to cherry tomatoes, not to forget that phytoavailability is also influenced by other factors related to soil ( $\mathrm{pH}$, redox, Cationic exchange capacity) (temperature, humidity), plant species, soil microorganisms, cultivation techniques, characteristics of elements and interactions between them [8].

\section{Materials and Methods}

The experimental process undergoes two successive cultivation phases. The first is the planting of cherry tomato seeds in plastic cups, and then an under-shelter BIOTOP device transplantation, which allows the development of tomato seedl- 


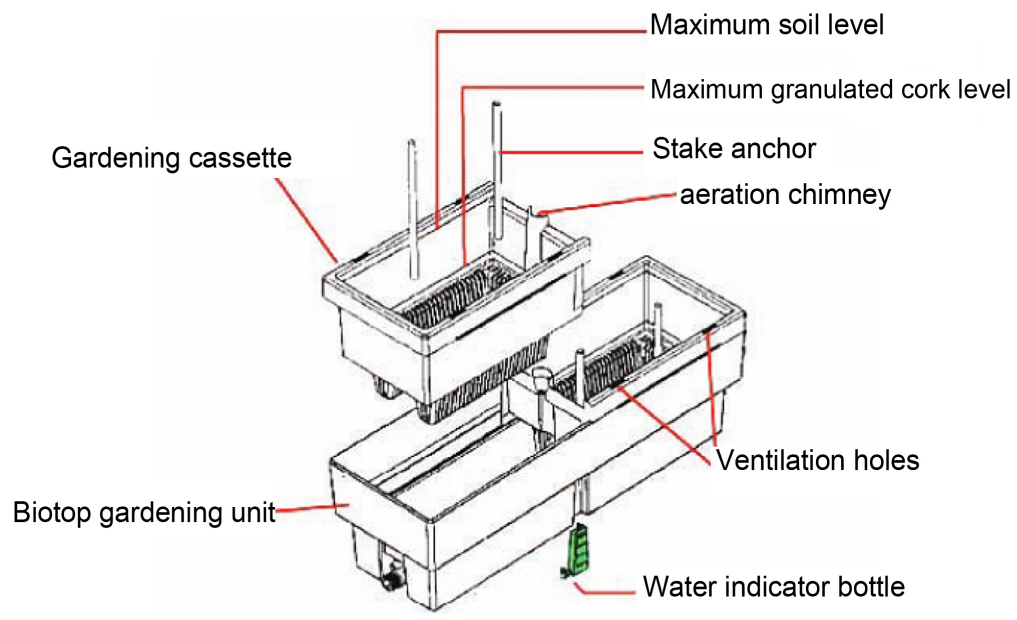

(a)

ings under bioponic conditions. This device comprises a bunch of 7 planting box, each box contains two trays with one plant for each. These two trays contain a layer of compost ( $80 \%$ of the organic matter) which rests on an inert substratum (granulated cork), the whole is irrigated by a stream which contains distilled water with a fertilizer solution (NPK 6.6.6) and trace elements, which provides the plants with the essential mineral salts (Figure 1).

The $\mathrm{pH}$ is adjusted to 6 with sodium bicarbonates and the conductivity is maintained at $2.4(\mathrm{~m} \cdot \mathrm{s} / \mathrm{cm})$. The contaminant concentrations were retained at 5 ppm, 10 ppm and 20 ppm respectively. After sufficient development of the root system, usually one month after seedling, the contaminant is then added. Thus, two boxes are fed with the 5 ppm concentration, with a box contaminated with chromium and the other with lead. The same goes for the $10 \mathrm{ppm}$ and $20 \mathrm{ppm}$ concentrations. The 7 th box was reserved for control purposes.

The plants are trimmed in vertical cordon, and the suckers are eliminated step by step during the plant growing process. To have an early product and allow fruit to grow rapidly, only three floral bouquets are kept. No disease has been detected. The experiment lasted four months, from the seedling of the seeds to the ripening of all fruits of the three floral bouquets (Figure 2).

\subsection{Sample Preparation and Characterization}

The water-based samples are put in polyethylene bottles previously washed with soap, then acid $(10 \% \mathrm{HCl})$ and finally rinsed several times with distilled water. The samples were then fixed with $2 \% \mathrm{HNO}_{3}$. The cultivation soil was extracted from the surface (up $5 \mathrm{~cm}$ of thickness) using a non-metallic tool and stored in clean plastic bags at low-temperature. The cherry tomato plants are carefully washed (essentially the roots) and put in clean plastic bags and kept at low temperature as well.

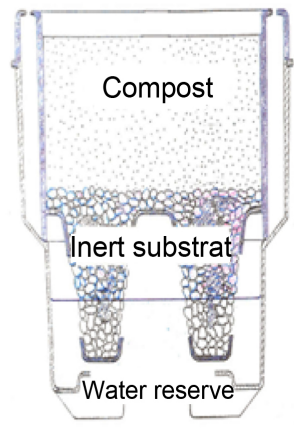

(b)

Figure 1. (a) Description of the system and of its accessories, (b) Spatial and functional segregation of roots in two distinct environments. 


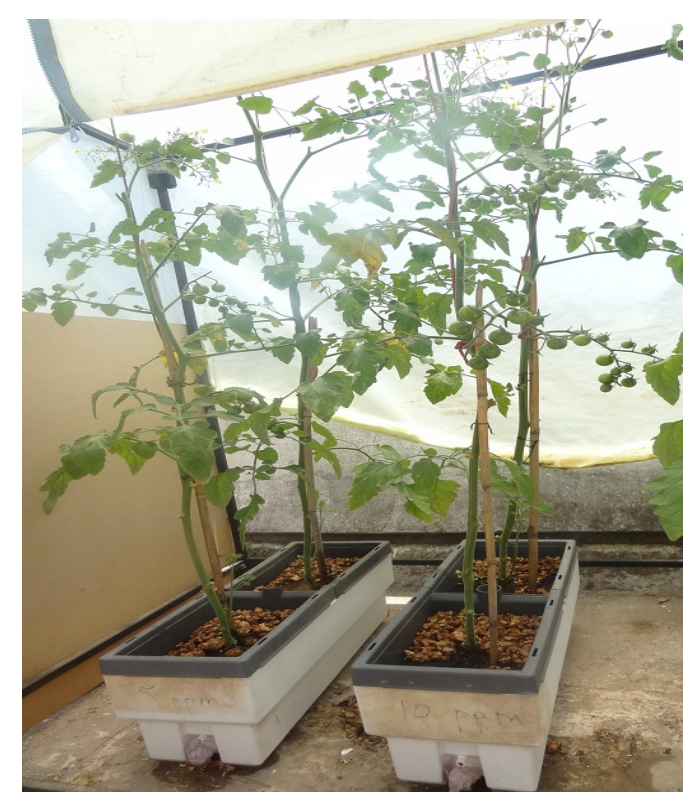

Figure 2. Plants of cherry tomato in Biotop device.

\subsection{Technical Analysis}

The water samples are filtered with Whatman 40 filter paper. The filtrate has been stored at $4^{\circ} \mathrm{C}$ until the analysis of the metals. The cultivation soil was dried in an oven $\left(105^{\circ} \mathrm{C}\right.$.) for 24 hours and then crushed in an Agathe mortar and later homogenized. The cherry tomato plants are rinsed beforehand with tap water, and then abundantly cleansed with distilled water. The different parts of the plant (roots, stems, leaves and fruits of the first, second and third floral bouquet) are separated, cut into pieces and dried in an oven $\left(105^{\circ} \mathrm{C}\right)$ for 24 hours, and then ground.

The digestion protocols concerning the preparation of samples for the quantitative analysis of lead $(\mathrm{Pb})$ and chromium $(\mathrm{Cr})$ in the growing soil and the cherry tomato plants are as follows:

Cultivation soils: $0.2 \mathrm{~g}$ in Teflon bombs of $30 \mathrm{ml}$. To this was added $1 \mathrm{ml}$ of the hydrochloric acid (30\%)-nitric acid (65\%), 3/1; V/V and $6 \mathrm{ml}$ of pure Norma hydrofluoric acid. The bombs are then closed and kept for pre-digestion at room temperature for 24 hours. They are then heated at $120^{\circ} \mathrm{C}$ for 4 hours in a thermostatic sand bath. After cooling, the volume is completed to $50 \mathrm{ml}$ by bidistilled water in dilution tubes containing $2.7 \mathrm{~g}$ of boric acid [9].

A control is always prepared in parallel with the samples, and we did three replicates for each sample.

Cherry tomato plants: $0.5 \mathrm{~g}$ of sample were weighed into Teflon digestion bombs, in each of which $4 \mathrm{ml}$ of supra-pure nitric acid (65\%) is added before closing and keeping them for pre-digestion at room temperature throughout 24 hours. The bombs are then placed in a sand bath at $120^{\circ} \mathrm{C}$ until the solutions become clear and lucid (usually after 24 hours). After cooling, the contents of the bombs are transferred into dilution tubes of $50 \mathrm{ml}$ and completed to $50 \mathrm{ml}$ 
with bidistilled water [10].

The metal testing is then carried out at UATRS laboratory of National Centre for Technical and Scientific Research (CNRST) in Rabat, Morroco.

\section{Results}

\subsection{Evaluation of Phytoaccumulation of Lead and Chromium in Water, Cultivation Soil and Different Parts of Cherry Tomato Plant}

We have observed and concluded that the roots are the most contaminated (Figure 3 and Figure 4), followed by the stem and then the leaves. The fruits of

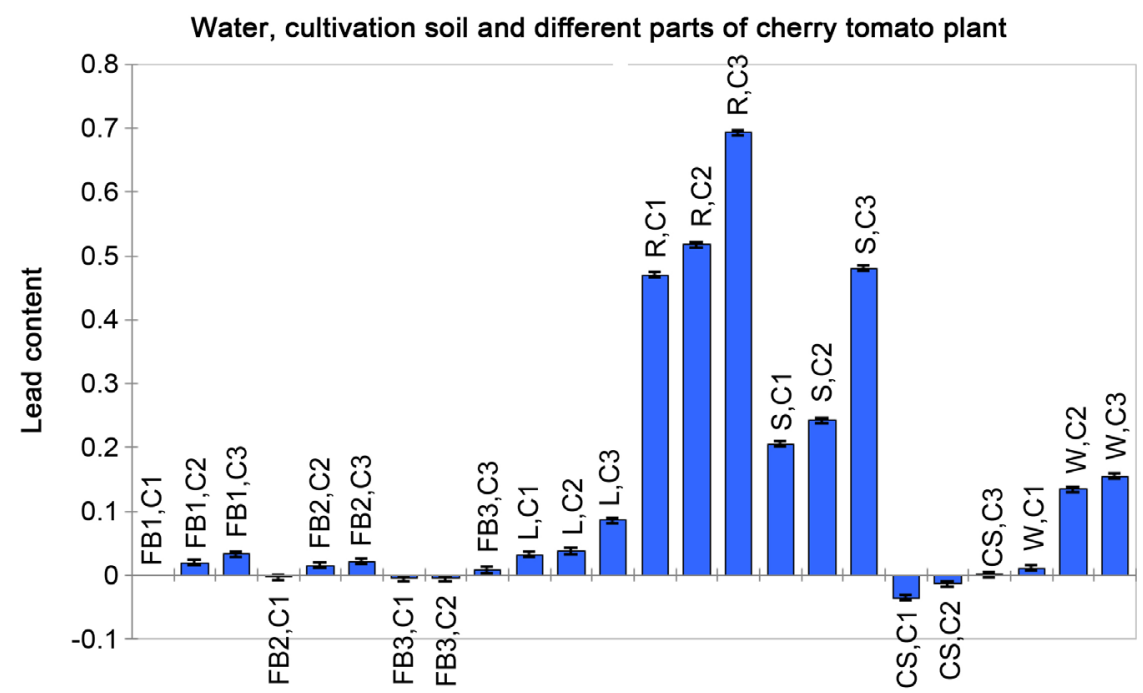

Figure 3. Lead content in water, cultivation soil and different parts of cherry tomato plant. W: water, CS: cultivation soil, R: roots, S: stem, L: leaves, FBi: fruits of floral bouquets i. C1: 5 ppm, C2: 10 ppm, C3: 20 ppm.

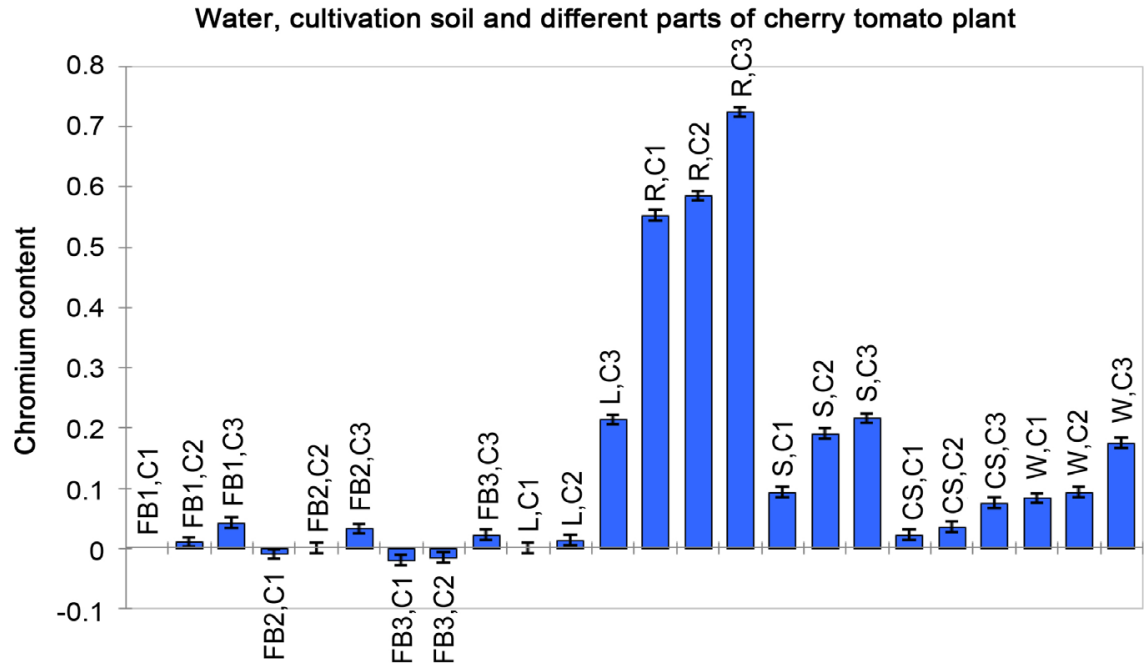

Figure 4. Chromium content in water, cultivation soil and different parts of cherry tomato plant. W: water, CS: cultivation soil, R: roots, S: stem, L: leaves, FBi: fruits of floral bouquets i. C1: 5 ppm, C2: 10 ppm, C3: 20 ppm. 
the three floral bouquets, however, are the least contaminated.

We have also noted that the contents of the two contaminants are always higher in water than those in cultivation soil and this apply for all three concentrations, yet they are much lower than those at the level of roots.

The percentage of lead translocation into the different parts of the cherry tomato plant shows no variation (Figure 5), according of course to each increase in concentration. As a result, an average of $38 \%$ of the total metal substance is found in the roots, $24 \%$ in the stem, $11 \%$ in the leaves and $26 \%$ in the fruit.

By contrast, the chromium average translocation prevails mainly in the roots (62\%) compared to that of lead (38\%) (Figure 6), bearing in mind though that it changes according to the concentration of the contaminant over the different parts of the plant. For the more the contaminant concentration increases, the less the percentage of its content becomes at the level of roots and higher it gets at the level of the fruit.

The Concentrations of element trace are commonly higher in the belowground parts (roots and rhizomes) as compared to aboveground parts (stems, leaves, flowers of fruits) of wetland plant [11] [12] because the roots are primary sites for heavy metals uptake and the further movement to aboveground parts may be restricted [13]. Same results for vegetable plants such as cherry tomato.

The higher bioaccumulation of lead in the fruit could be explained by phloem mobility, which depends heavily on the compounds' physicochemical properties, such as lipophilicity and pKa. Ionic element trace may be trapped in the phloem, resulting in lower concentrations in the leaves and potentially higher accumulation in the fruit.

Another conclusion is related to the physiology of the plant: the better the
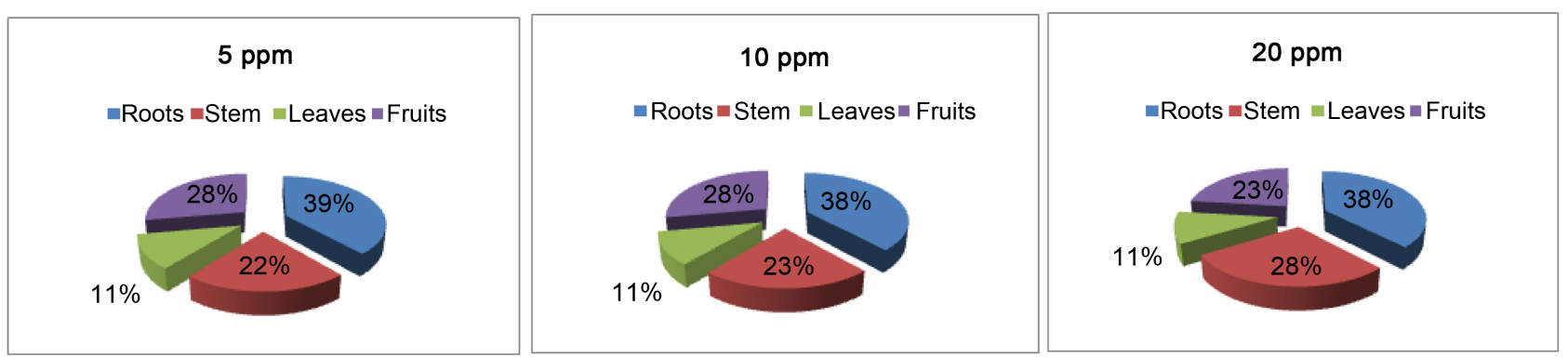

Figure 5. Lead distribution percentage in different parts of cherry tomato plant.
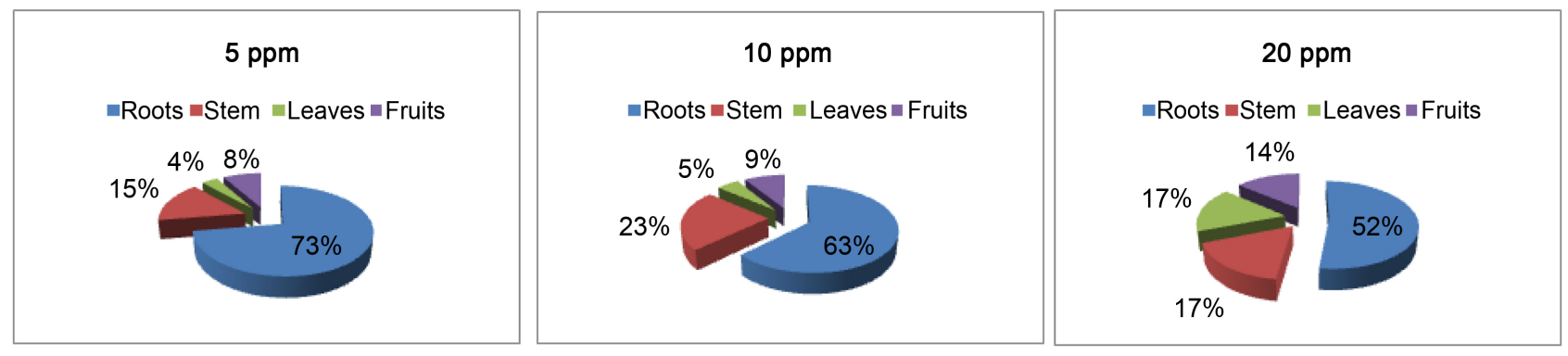

Figure 6. Chromium distribution percentage in different parts of cherry tomato plant. 
fruit's ability to transpire water, the higher the risk of trace element accumulation within the fruit.

\subsection{Evaluation of Phytoaccumulation of Lead and Chromium Depending on the Concentration}

The analysis of variance and Tukey's test (HSD) for multiple comparisons of averages 5\% were performed using the software Xlstat.

The concentrations of $5 \mathrm{ppm}$ are very low and do not appear graphically.

Hence, the contents of lead and chromium in the various parts of the cherry tomato plant (roots, stem, leaves and fruits) (Figure 7) vary according to the concentration applied. The higher the latter is, the more significant is the content in each compartment. One should note that the level of lead and chromium is insignificant in the control plant.

According to Tukey's test, $\mathrm{p}<0.05$, there is no significant difference between the three concentrations for the two contaminants.

From the analysis of the box plots of lead and chromium (Figure 8), it is found that lead has a greater effect on the plant compared to chromium; the lead presence in the plant is higher compared to that of chromium.

\section{Discussion}

In fact, after the analysis of lead and chromium distribution in cherry tomato plants (Figure 3 and Figure 4), it is inferred that accumulation occurs mainly at the level of the root, with concentrations decreasing from roots to fruits. This suggestion is also confirmed by [14] which have found that tomatoes grown in soil with a contribution of contaminated sludge that chromium also accumulates significantly in the roots and a low content that pass to leaves and fruits. Another contaminant that is cadmium, have also been reported to be present in roots of tomato grown in hydroponics more than in shoots [15]. Also those of [16], who had a similar results for concentrations of $\mathrm{Zn}$ in root tissues of eighteen emergent wetland plant species exposed to $\mathrm{Zn}$ in hydroponic culture.

Lead is mainly resided (more than 50\%) in the aerial organs for cherry tomato plant (Figure 5); a same result was found by [17] for B. pilosa and T. Minuta.

Only for chromium, (Figure 6) belowground accumulation was higher than aboveground accumulation in cherry tomato plant and also in P. australis plant, [18], this study are consistent with the findings of [19] who had similar results for arsenic and heavy metals in the two plants $C$. alternifolius and E. amazonicus. Same results also for rice root that acted as a more effective barrier to lead accumulation, [20].

In general roots possess real barriers controlling access to the rest of the plant, yet, despite this restriction of access, in general, we note an upward bioaccumulation of these metals according to the following order: root $>$ stem $>$ leaf $>$ fruit [21].

We also observe that the concentrations in the cherry tomato plant differ as per to each metal. Lead is higher than chromium. As far as the Figure 5 and 

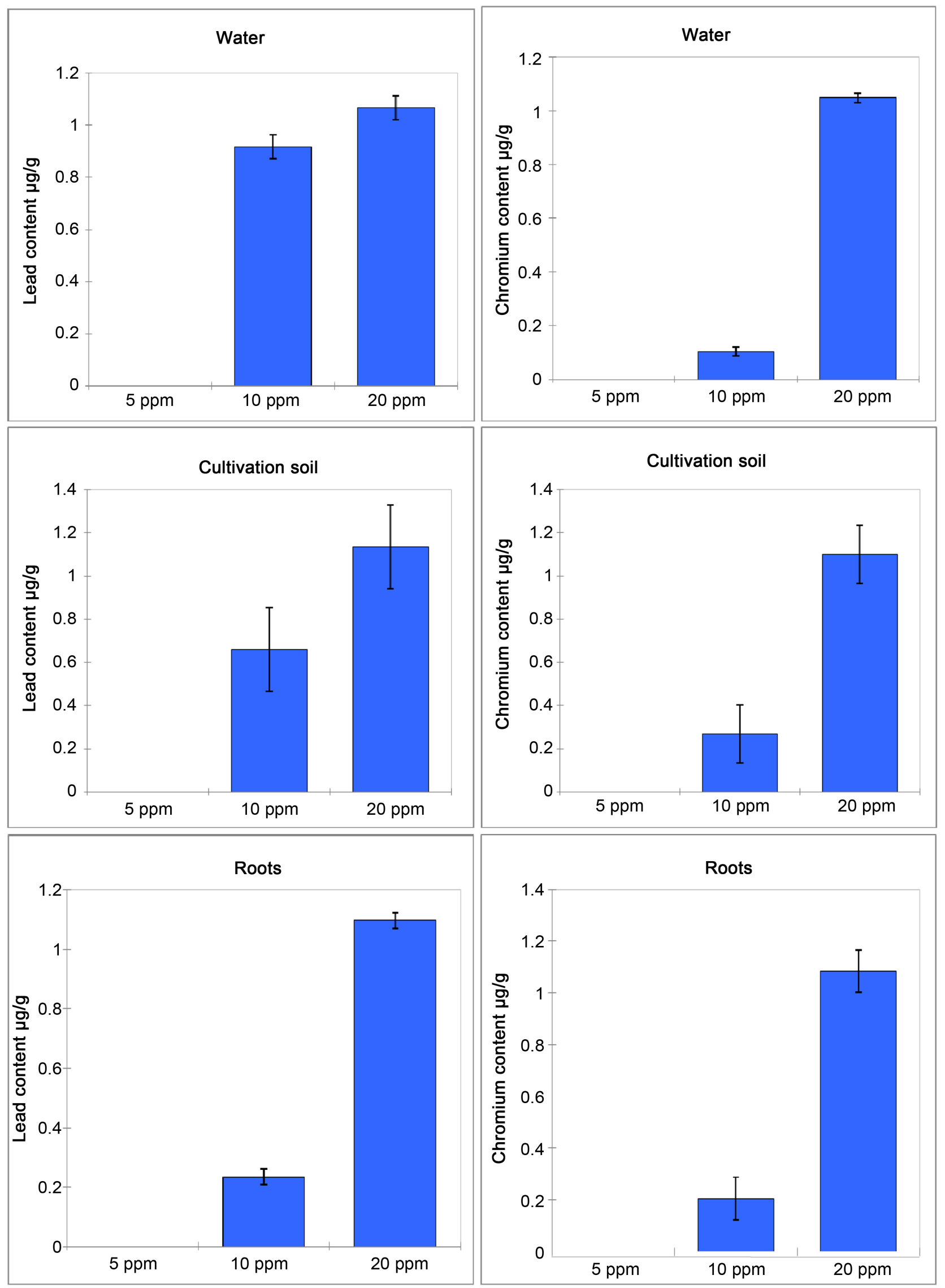

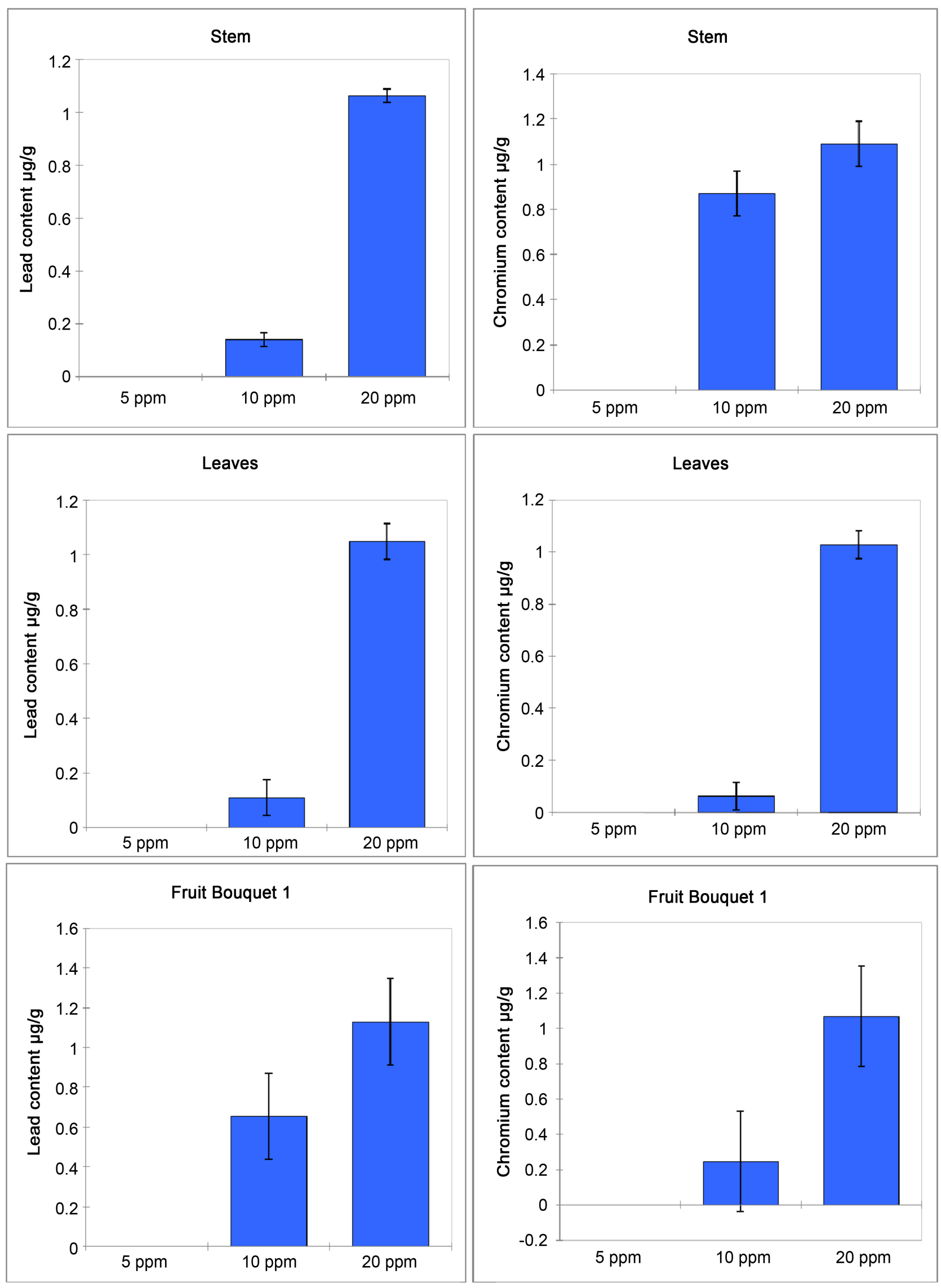

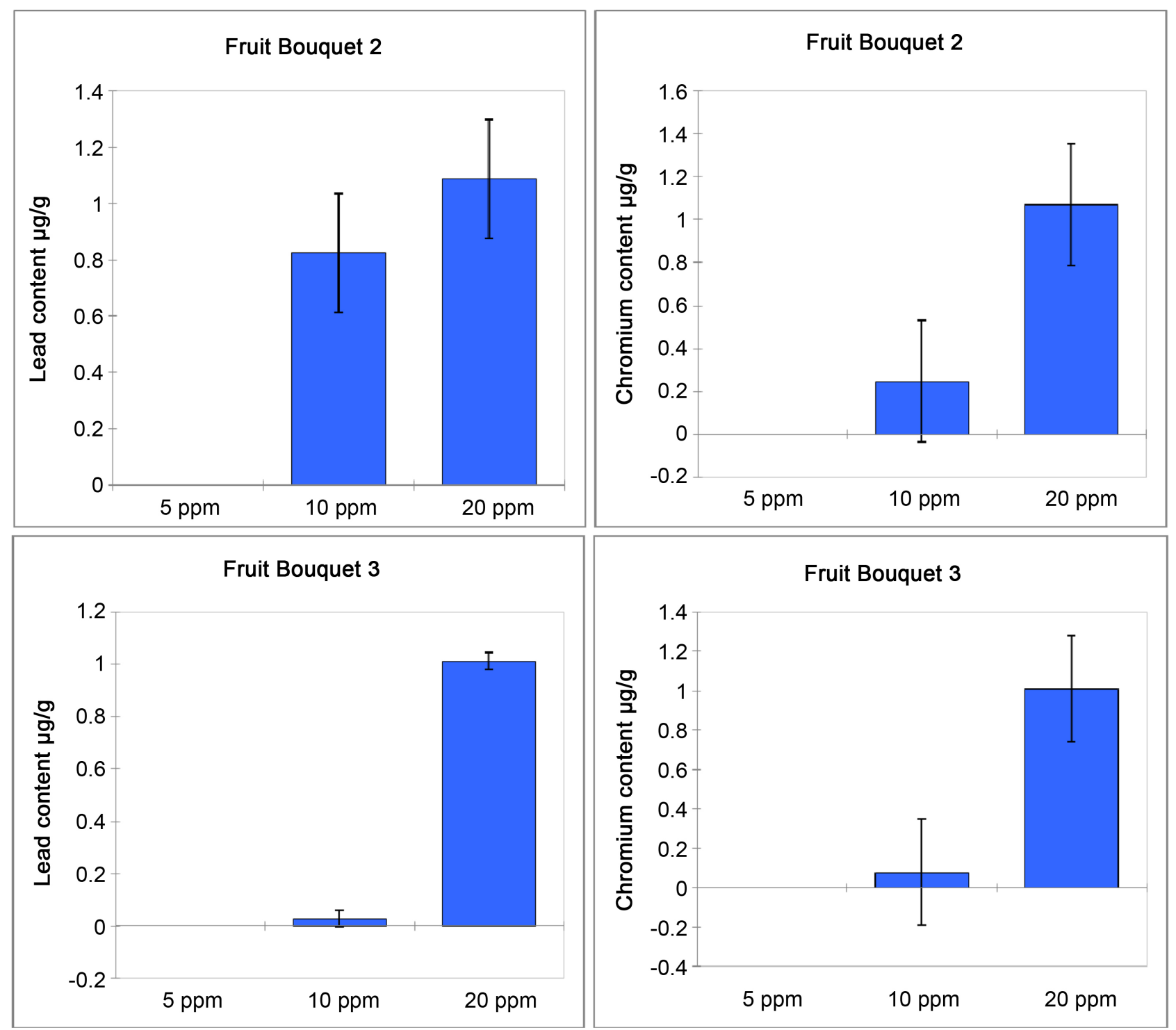

Figure 7. Content of lead and chromium in cherry tomato plants for the three concentrations, $5 \mathrm{ppm}, 10 \mathrm{ppm}$ and $20 \mathrm{ppm}$, with three repetitions for each concentration.

Figure 6, it is also noted that the average distribution of lead (26\%) in the edible part of the plant is much higher than that of chromium (10\%). Therefore, such an accumulation in the edible part of the plant could have implications on human health.

The contents of lead and chromium in the various parts of the cherry tomato plant (roots, stem, leaves and fruits) (Figure 7) vary according to the concentration applied, same results for tomato have also been found by [22].

Chromium is not an essential nutrient for plants A few studies have shown that chromium in relatively small quantities may promote plant productivity [23] [24], It is for this reason that we find that the chromium concentration in the plant is less important than that of lead, (Figure 8), it may be that a part has been absorbed and used by the plant during its development process. 


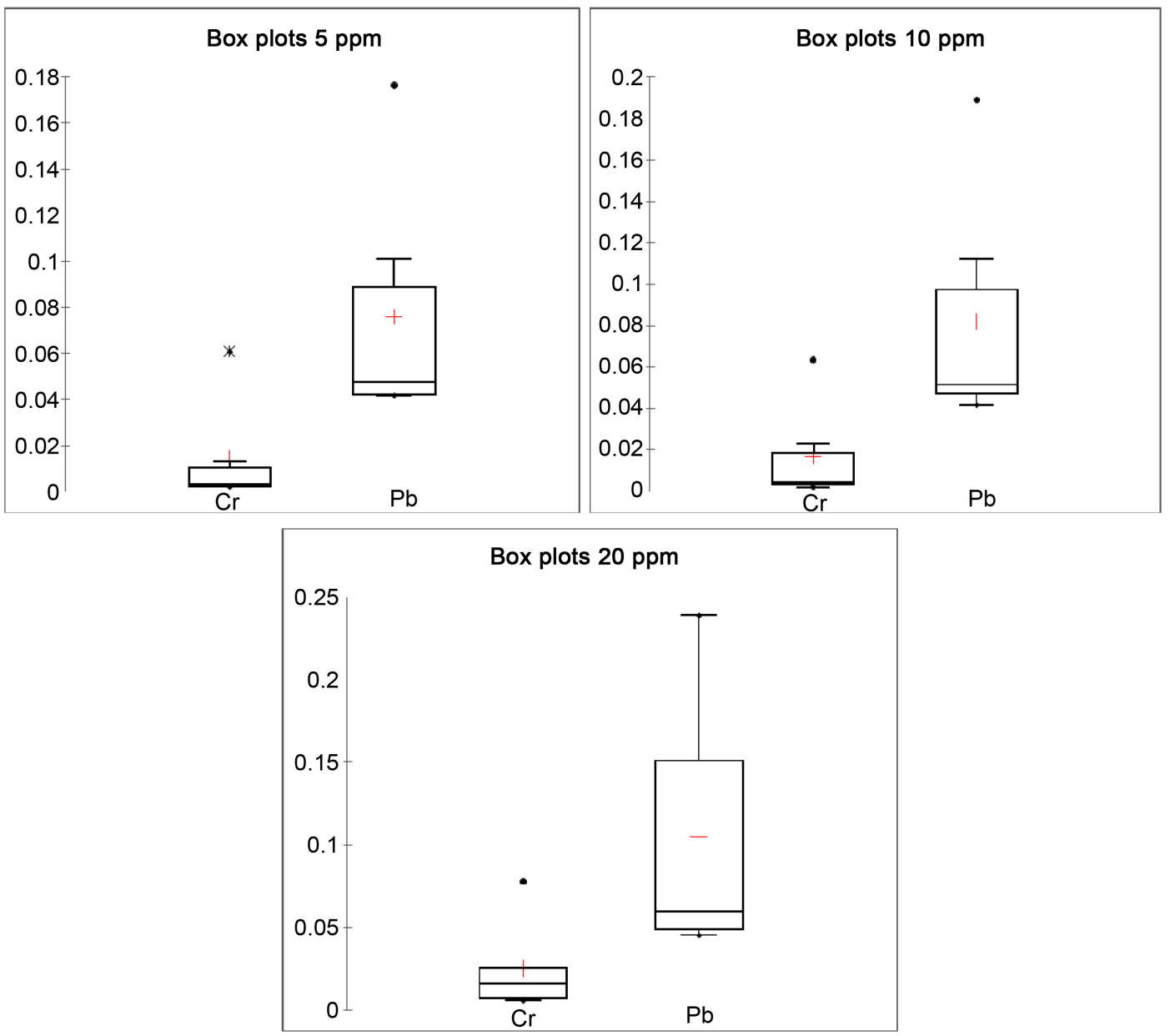

Figure 8. Box plots of the two variables lead and chromium.

\section{Conclusions}

In water and cultivation soil, lead content is higher than that of chromium in different concentrations levels of the contaminant.

Now, regarding the analysis of the presence of the two contaminants at the different parts of the plant, the latter generally shows an inclination to accumulating said contaminants within the whole plant, but preferentially within the roots.

Once accessing the root, the two trace elements permeate in the different organs of the plant. Their contents are higher in the leaves and stems than in the fruits, however. During the permeation process, the metals are fixed largely on the cell walls, which explain why most of the metals collected are found in the roots while only a smaller amount is found in the sprout.

To conclude, the roots play the role of a real barrier restricting access into the rest of the plant. However, despite such restriction, we notice a slight increasing bioaccumulation of these metals in the cherry tomato plant.

The limitation of this research is that we cannot make such a test for plants that we consume the stem, for example the turnips, or the plants whose leaves 
are consumed such as celery, because it's difficult to follow the passage of the contaminant according to the logic: root/stem/leaf/fruit.

\section{Acknowledgements}

This manuscript was produced in collaboration between the Scientific Institute and the Faculty of Sciences of Rabat. The authors thank the reviewers for comments and remarks that will improve the manuscript.

\section{Conflict of Interest}

The authors declare that they have no conflict of interest.

\section{References}

[1] Fraga, C.G. (2005) Relevance, Essentiality and Toxicity of Trace Elements in Human Health. Molecular Aspects of Medicine, 26, 235-244.

https://doi.org/10.1016/j.mam.2005.07.013

[2] Khairiah, J., Yu, H.Y., Khairal, N.I., Ang, W.W., Aminah, A., Maimon, A., Zalifah, M.K. and Geri, A.K. (2002) Bioavailability of Chromium in Vegetables of Selected Agricultural Areas of Malaysia. Pakistan Journal of Biological Sciences, 5, 471-473. https://doi.org/10.3923/pjbs.2002.471.473

[3] Antunes, W.M., Luna, A.S., Henriques, C.A. and Da Costa, A.C.A. (2003) An Evaluation of Copper Biosorption by Brown Seaweed under Optimized Conditions. Electronic Journal of Biotechnology, 6, 174-184.

[4] Jamal, S.N., Zafa, I.M. and Athar, M. (2006) Effect of Aluminium and Chromium on the Germination and Growth of Two Vigna Species. International Journal of Environmental Science and Technology, 3, 53-58. https://doi.org/10.1007/BF03325907

[5] Peralta, J.R., Gardea, R.T.L., Thiemann, K.J., Gomez, E., Arteaga, S.R.E. and Parsons, J.G. (2000) Study of the Effects of Heavy Metals on Seed Germination and Plant Growth of Alfalfa Plant (Medicagos sativa) Grown in Solid Media. Proceedings of the 2000 Conference of Hazardous Waste Research, 135, 1-6.

[6] Marcovecchio, J.E., Botté, S.E. and Freije, R.H. (2007) Heavy Metals, Major Metals, Trace Elements. In: Nollet, L.M.L., Ed., Handbook of Water Analysis, 2nd Edition, CRC Press, Boca Raton, 275-311. https://doi.org/10.1201/9781420006315.ch11

[7] Chaignon, V. (2001) Biodisponibilité du cuivre dans la rhizosphère de différentes plantes cultivées. Cas de sols viticoles contaminés par des fongicides. Thèse: Ecole Doctorale, Sciences de l'Environnement: Système Terre, Université d'Aix-Marseille.

[8] Tremel-Schaub, A. and et Feix, I. (2005) Contamination des sols-Transferts des sols vers les plantes. Agence de l'Environnement et de la Maîtrise de l'Énergie, 413 p.

[9] Chiffoleau, J.-F., Cossa, D., Auger, D. and Truquet, I. (1994) Trace Metal Distribution, Partition and Fluxes in the Seine Estuary in Low Discharge Regime. Marine Chemistry, 47, 145-158. https://doi.org/10.1016/0304-4203(94)90105-8

[10] Auger, D. (1989) Méthode de dosage du plomb, du cadmium, du cuivre et du zinc dans les milieux biologiques. Direction de l'environnement et de recherches océaniques. DERO-89-07-MR.

[11] Galletti, A., Verlicchi, P. and Ranieri, E. (2010) Removal and Accumulation of Cu, $\mathrm{Ni}$ and $\mathrm{Zn}$ in Horizontal Subsurface Flow Constructed Wetlands: Contribution of Vegetation and Filling Medium. Science of the Total Environment, 408, 5097-5105. 
[12] Fawzy, M.A., El-Sayed Badr, N., El-Khatib, A. and Abo-El-Kassem, A. (2012) Heavy Metal Biomonitoring and Phytoremediation Potentialities of Aquatic Macrophytes in River Nile. Environmental Monitoring and Assessment, 184, 1753-1771. https://doi.org/10.1007/s10661-011-2076-9

[13] Clemens, S., Palmgreen, M.G. and Kramer, U. (2002) A Long Way Ahead: Understanding and Engineering Plant Metal Accumulation. Trends in Plant Science, 7, 309-315.

[14] Kassaoui, H., Lebkiri, M., Lebkiri, A., El Rifi, H., Badoc, A. and Douira, A. (2009) Bioaccumulation of Heavy Metals in Tomato and Lettuce Fertilised with Sludge from a Wastewater Treatment Plant. Bulletin of the Society of Pharmacy of Bordeaux, 148, 77-92.

[15] Lopez-Millan, A., Sagardoy, R., Solanas, M., Abadia, A. and Abadia, J. (2009) Cadmium Toxicity in Tomato (Lycopersicon esculentum) Plants Grown in Hydroponics. Environmental and Experimental Botany, 65, 376-385.

[16] Yang, J., Tam, N.F.-Y. and Ye, Z. (2014) Root Porosity, Radial Oxygen Loss and Iron Plaque on Roots of Wetland Plants in Relation to Zinc Tolerance and Accumulation. Plant Soil, 374, 815-828. https://doi.org/10.1007/s11104-013-1922-7

[17] Salazara, M.J., Rodriguez, J.H., Cid, C.V., Bernardelli, C.E., Donati, E.R. and Pignata, M.L. (2016) Soil Variables That Determine Lead Accumulation in Bidens pilosa L. and Tagetes minuta L. Growing in Polluted Soils. Geoderma, 279, 97-108.

[18] Vymazal, J. (2015) Concentration Is Not Enough to Evaluate Accumulation of Heavy Metals and Nutrients in Plants. Science of the Total Environment, 544, 495-498.

[19] Yang, J.X., Guo, Q.J., Yang, J., Zhou, X.Y., Ren, H.Y., Zhang, H.Z., Xu, R.X., Wang, X.D., Peters, M., Zhu, G.X., Wei, R.F., Tian, L.Y. and Han, X.K. (2016) Red Mud (RM)-Induced Enhancement of Iron Plaque Formation Reduces Arsenic and Metal Accumulation in Two Wetland Plant Species. International Journal of Phytoremediation, 18, 269-277.

[20] Yang, J., Liu, Z., Wan, X., Zheng, G., Yang, J., Zhang, H., Guo, L., Wang, X., Zhou, X., Guo, Q., Xu, R., Zhou, G., Peters, M., Zhu, G., Wei, R., Tian, L. and Han, X. (2016) Interaction between Sulfur and Lead in Toxicity, Iron Plaque Formation and Lead Accumulation in Rice Plant. Ecotoxicology and Environmental Safety, 128, 206-212.

[21] Prasad, M.N.V. and Hagemeyer, J. (1999) Heavy Metal Stress in Plants-From Molecules to Ecosystems. Springer-Verlag, Heidelberg, Berlin, New York, 401. https://doi.org/10.1007/978-3-662-07745-0

[22] Opeolu, O., Adenuga, O.O., Ndakidemi, P.A. and Olujimi, O.O. (2010) Assessment of Phyto-Toxicity Potential of Lead on Tomato (Lycopersicon esculentum L) Planted on Contaminated Soils. International Journal of Physical Sciences, 5, 68-73.

[23] Zayed, A.M. and Terry, N. (2003) Chromium in the Environment: Factors Affecting Biological Remediation. Plant Soil, 249, 139e156.

[24] Prasad, A., Singh, A.K., Chand, S., Chanotiya, C.S. and Patra, D.D. (2010) Effect of Chromium and Lead on Yield, Chemical Composition of Essential Oil, and Accumulation of Heavy Metals of Mint Species. Communications in Soil Science and Plant Analysis, 41, 2170e2186. 
Submit or recommend next manuscript to SCIRP and we will provide best service for you:

Accepting pre-submission inquiries through Email, Facebook, LinkedIn, Twitter, etc. A wide selection of journals (inclusive of 9 subjects, more than 200 journals)

Providing 24-hour high-quality service

User-friendly online submission system

Fair and swift peer-review system

Efficient typesetting and proofreading procedure

Display of the result of downloads and visits, as well as the number of cited articles Maximum dissemination of your research work

Submit your manuscript at: http://papersubmission.scirp.org/

Or contact gep@scirp.org 